\title{
AKTUALISASI ANTINOMI NILAI-NILAI FILOSOFIS PASAL 33 UUD 1945
}

\author{
Jundiani \\ Fakultas Syariah UIN Maulana Malik Ibrahim Malang \\ jundis3@yahoo.com
}

\begin{abstract}
Abstrak
Object of study of this research is the actualization of antinomy of philosophical values Article 33 of the Constitution of 1945 in realizing the greatest social welfare. The legal study raised issues related to: 1) the antinomy of philosophical values of Article 33 of the Constitution of 1945 and 2) the actualization of philosophical values of Article 33 of the Constitution of 1945 in realizing the greatest social. The purpose of the study is to determine the legal paradigm and philosophical values of enforceability of law in article 33 of the Constitution of 1945 in order to realize the greatest welfare of the people. The results of the study showed there is legal paradigm that enriches understanding of the values of legal philosophical values; the value of legal certainty, the value of legal justice, and the value of the benefit of the law, as stated in article 33 of the Constitution of 1945. The actualization of the values of the legal philosophic stated in Article 33 of the Constitution 1945 in order to achieve the greater social welfare. Setting the philosophical values and putting on the legal norms on social and economic activities in the formation of legislation under Article 33 of the Constitution of 1945 is based on the responsive legal paradigm, namely the development of legal philosophical values in legislation.

Objek kajian dari penelitian ini adalah aktualisasi antinomi nilai-nilai filosofis Pasal 33 Undang-Undang Dasar 1945 dalam mewujudkan sebesar-besarnya kemakmuran rakyat. Pengkajian hukum tersebut mengangkat permasalah terkait dengan: 1) antinomi nilai-nilai filosofis Pasal 33 Undang-Undang Dasar 1945 dan 2) aktualisasi nilai-nilai filosofis Pasal 33 Undang-Undang Dasar 1945 dalam mewujudkan sebesar-besarnya kemakmuran rakyat. Tujuan pengkajian adalah menentukan paradigma hukum dan nilai-nilai filosofis keberlakuan hukum dalam Pasal 33 Undang-Undang Dasar 1945 di dalam rangka mewujudkan sebesar-besarnya kemakmuran rakyat. Hasil penelitian menunjukkan paradigma hukum yang memperkaya pemahaman nilai-nilai filosofis hukum baik nilai kepastian hukum, nilai keadilan hukum maupun nilai kemanfaatan hukum, sebagaimana tersirat dalam Pasal 33 Undang-Undang Dasar 1945. Aktualisasi nilai-nilai filosofis hukum dilakukan terhadap Pasal 33 Undang-Undang Dasar 1945 dalam rangka pemenuhan sebesar-besarnya kemakmuran rakyat. Pengaturan nilai-nilai filosofis hukum dan pernormaan kegiatan sosial dan ekonomi dalam pembentukan peraturan perundangundangan menurut Pasal 33 Undang-Undang Dasar 1945 berdasarkan paradigma hukum responsif, yaitu atas pengembangan nilai-nilai filosofis dalam peraturan perundangundangan.
\end{abstract}

Kata Kunci: Antimomi Nilai, Undang-Undang Dasar, Kesejahteraan Rakyat 
Sejarah lahirnya Negara Indonesia telah memberikan catatan penting serta menunjukkan perbedaan pemikiran di bidang perekonomian dan sosial yang akan digunakan dalam praktek penyelenggaraan kenegaraan. Perdebatan pengaturan kebijakan perekonomian dan sosial secara nasional dalam konstitusi sudah dimulai sejak akan dilahirkannya konstitusi sebagai dasar penyelenggaraan kehidupan bernegara dan berbangsa Indonesia. Para pendiri bangsa, The Founding Fathers, masingmasing telah mengemukakan dasar-dasar filosofis penyelenggaraan kegiatan ekonomi nasional dari pendapat atau pandangan yang diajukannya dalam rapat-rapat persiapan kemerdekaan Republik Indonesia. ${ }^{1}$ Sejarah perdebatan terulang kembali setelah adanya upaya dilakukannya perubahan UndangUndang Dasar 1945, berkenaan dengan hak dan kewajiban konstitusional sebagaimana termuat dalam Pasal 33 dan Pasal 34 UndangUndang Dasar 1945. ${ }^{2}$

Perdebatan konstitusionalisasi demokrasi ekonomi dan sosial oleh The Founding Fathers sebelum berdirinya Negara Indonesia dipengaruhi oleh dinamika diskursus konstitusi sosial dan ekonomi dari berbagai negara, yang mengikuti pola konstitusionalisasi ekonomi dan sosial selaras dengan kondisi masing-masing negara. Berbagai ragam tipologi konstitusionalisasi sosial dan ekonomi bermunculan sesuai dengan dinamika negara dalam menjalankan kebijakan sosial maupun ekonominya. Hal ini selaras dengan pengaturan hak konstitusional untuk mendapatkan kondisi perekonomian dan sosial yang kokoh, sehat dan stabil yang didasarkan pada filsafat dasar kehidupan bernegaranya. ${ }^{3}$ Konstitusi yang memuat hak konstitusional warga negara maupun kebijakan dalam penyelenggaraan kegiatan sosial dan ekonomi dari masing-masing negara dapat

${ }^{1}$ R.M. Ananda B. Kusuma, “Teori Konstitusi dan UUD 1945", Jurnal Konstitusi Mahkamah Konstitusi 3, No 2, (Mei 2006), h. 152.

2Jimly Asshiddiqie, Konstitusi Ekonomi, (Jakarta: Penerbit Buku Kompas, 2010), h. ix.

${ }^{3}$ Dahlan Thaib, et.al., Teori dan Hukum Konstitusi ( Jakarta: Rajawali Press, 1999), h. 9. dikualifikasikan berdasarkan karakter sebagai negara liberal-kapitalistik, negara sosial-komunis dan negara-negara yang tidak menganut kedua paham tersebut. Beberapa negara yang menganut paham liberal-kapilastik maupun social-komunis telah melaksanakan kebijakan ekonominya sesuai dengan kondisi negaranya. Negara-negara yang tidak menganut paham liberal-kapitalistik maupun sosial-komunis berupaya melakukan simbiosis mutualistik atas kedua paham tersebut yang pada awalnya senantiasa berhadap-hadapan atau pertentangan secara mendasar (ideologis).

Perdebatan paham liberal-kapitalistik dengan paham sosial-komunis mewarnai pula dalam sejarah penyusunan konstitusi sosial dan ekonomi. Paham liberal-kapitalistik ini mengatur jaminan hak milik individual, kebebasan berkontrak dan kompetisi diantara pelaku usaha merupakan hal yang mengemuka dalam kebijakan ekonominya. ${ }^{4}$ Berbeda dengan paham sosialis-komunis yang beranjak pada peran Negara yang diwakili pemerintah yang demikian besarnya sehingga disebut sebagai aktor utama dalam kegiatan perekonomian termasuk dalam merumuskan kebijakan perekonomiannya. Sejalan dengan besarnya peran pemerintah tersebut maka Negara dengan paham sosial-komunis memberikan pengakuan bahwa segala sumber daya alam dan kekayaan yang terkandung didalamnya dimiliki oleh Negara, yang termasuk juga adalah alat produksi dan lainnya.

Jimly Asshiddiqie ${ }^{5}$ mengemukakan terjadinya perdebatan konstitusionalisasi pengaturan hak konstitusional warga negara dan penyelenggaraan kegiatan ekonomi yang terjadi seputar amandemen Undang-Undang Dasar 1945 yang dilakukan antara Tahun 1999-2002. Sehubungan dengan perubahan Pasal 33 Undang-Undang Dasar 1945 maka telah terjadi perdebatan antara para ahli yang berpaham idealis dengan yang berpaham pragmatis. Kelompok pragmatis berupaya

${ }^{4}$ Dahlan Thaib, et.al. Teori dan Hukum Konstitusi, h. 9

${ }_{5}^{5}$ Jimly Assiddiqie, Konstitusi Ekonomi, h. ix. 
melakukan perubahan Pasal 33 UndangUndang Dasar 1945 dengan argumentasinya bahwa diperlukannya internalisasi nilai-nilai dan kaedah perekonomian global dalam perekonomian Indonesia. Perubahan memang tidak terjadi dalam Pasal 33 Undang-Undang Dasar 1945 akan tetapi dalam Pasal tersebut telah terjadi penambahan ayat yang diusulkan oleh para ahli yang berpaham pragmatis. Jimly Asshiddiqie ${ }^{6}$ berpendapat bahwa dengan penambahan ayat tersebut telah menimbulkan kerentanan bagi perekonomian Indonesia. Paradigma hukum dan nilai-nilai filosofis yang ditanamkan dalam kebijakan perekonomian adalah merupakan agenda ekonomi internasional seperti privatisasi, swastanisasi, komersialisasi maupun deregulasi.

Dalam rangka menumbuh-kembangkan kegiatan perekonomian sosial dan ekonomi dalam kehidupan berbangsa dan bernegara sebagaimana telah digariskan dalam konstitusi, secara umum telah diagendakan upaya ke depan yang lebih baik, sehat dan stabil. Dengan demikian keberadaan struktur sosial dan perekonomian yang ada sekarang ini perlu dikaji lagi keberadaannya. Hal ini terkait apakah struktur sosial dan perekonomian secara nasional telah berjalan sesuai dengan garis-garis kebijakan sebagaimana dirumuskan dalam konstitusi, serta perubahan-perubahan apa yang dapat diprediksi yang terjadi di masa depan. Begitu pun struktur sosial dan perekonomian perlu disempurnakan lagi untuk menampung segala perubahan yang terjadi serta akan menjadi bahan kajian untuk menentukan arah pengembangannya ke depan yang lebih baik. Hal ini dimaksudkan agar dapat mencapai tujuan kehidupan berbangsa dan bernegara Indonesia, yaitu sebesar-besar kemakmuran rakyatnya.

\section{Negara Hukum Modern}

Berawal dari sebuah konsep negara hukum dalam arti formal yang hanya menciptakan negara liberal, sehingga fungsi negara hanya sebagai negara penjaga malam (nachtwakersstaat).

\footnotetext{
${ }^{6}$ Jimly Assiddiqie, Konstitusi Ekonomi, h. ix.
}

Pada tahun 1930 negara liberal mengalami krisis ekonomi dan tidak dapat menuntaskan problema ekonomi tersebut pada sebagian besar negaranegara Barat, sehingga memunculkan gagasan pemikiran sebagai jawaban atas krisis tersebut adalah sebuah negara kesejahteraan. Menurut Muchsan, bahwa pemahaman negara hukum dalam arti formal tersebut telah ditinggalkan dalam era kelahiran negara hukum modern. Di dalam negara hukum modern beranjak pada pemahaman negara hukum dalam arti materiil. Di dalam negara hukum modern ini, negara dituntut untuk memberikan pelayanan yang sebaik-baiknya dan seluas-luasnya kepada masyarakat, sehingga semua lapisan masyarakat dapat menikmati kesejahteraan dalam kehidupannya. ${ }^{7}$

Pemaparan tentang perubahan pemikiran hukum yang terjadi dikalangan yuris amat penting disampaikan disini dengan pertimbangan adanya perubahan metode yang memberikan implikasi yang cukup luas dalam sejarah pemikiran hukum. Oleh sebab itu sebelum membahas antinomi nilai dan relasinya adalah penting untuk dikemukakan metode-metode pemikiran hukum baik yang terungkap dalam filsafat hukum, teori hukum, atau ilmu hukum. Di dalam hal ini antinomi nilai berada dalam tataran refleksi filsafat hukum. ${ }^{8}$. Negara Republik Indonesia menganut tipe negara hukum modern. Di dalam mewujudkan kesejahteraan kehidupan warganya, negara Republik Indonesia menekankan pada terciptanya masyarakat adil, makmur dan merata. Penggunaan konsepsinegara kesejahteraan bagi negara Republik Indonesia akan tampak dari dua fungsi yang dijalankan yakni fungsi regular (regularity function) dan fungsi pembangunan (developing function). Di dalam konteks kehidupan bernegara, upaya untuk mensejahterakan rakyat merupakan tujuan utama dibentuknya negara, sehingga

${ }^{7}$ Dahlan Thaib, et.al., Teori dan Hukum Konstitusi, h. 105-106

${ }^{8}$ Bernard Arief S, Refleksi Tentang Struktur Ilmu Hukum: Sebuah Penelitian tentang Fundasi Kefilsafatan dan Sifat keilmuan Ilmu Hukum Sebagai Landasan Pengembangan Ilmu Hukum Nasional Indonesia (Bandung: Mandar Maju, 2003), h. 138-144 
negara berupaya sepenuhnya dalam memenuhi kebutuhan hidup rakyatnya. Pemahaman ini menjadi pangkal tolak dalam penyelenggaraan kehidupan bernegara termasuk pengaturan kegiatan perekonomian masyarakat yang mensejahterakan masyarakatnya.

DiIndonesiapernah dikenal teoripembangunan hukum yang dikembangkan oleh Mochtar Kusumaatmadja. Teori tersebut dibangun atas teori kebudayaan Northop, teori orientasi kebijakan (policy-oriented) dari Laswell dan Mc Dougal serta teori hukum pragmatis dari Roscoe Pound ${ }^{9}$. Menurut Sidharta bahwa Mochtar Kusumaatmadja menolak mengidentikkan teori hukum pembangunan dengan utilitarianisme. Berbeda dengan Utilitarianisme yang kurang memperhatikan nilai-nilai budaya maka teori hukum pembangunan sangat memperhatikan nilai-nilai budaya di Indonesia. Teori hukum pembangunan dirancang kearah pengembangan ranah-ranah hukum netral, seperti di bidang transaksi bisnis, perdagangan dan pertambangan. Teori pembangunan hukum menjelaskan pembaharuan hukum melalui peraturan perundang-undangan dan penyaluran nilai-nilai atau aspirasi yang hidup dalam masyarakat. ${ }^{10}$

Secara tersirat maupun tersurat dari perumusan berbagai pasal sebagaimana tercantum di dalam Undang-Undang Dasar 1945, dapat dikemukakan mengenai paradigma hukum dan nilai-nilai hukum yang memberikan kedudukan bagi Undang-Undang Dasar 1945 sebagai konstitusi tertulis. Sebagaimana telah diketahui pengaturan di dalam Undang-Undang Dasar 1945 sebagai sebuah konstitusi negara, bukan hanya terkait dengan pengaturan lembaga-lembaga kenegaraan dan struktur pemerintahan semata. Akan tetapi secara subtansial mengatur sistem kehidupan berbangsa dan bernegara yang meliputi kehidupan politik, ekonomi dan sosial. Undang-Undang Dasar

\footnotetext{
${ }^{9}$ Mochtar Kusumaatmadja,Konsep Hukum dalam Pembangunan (Bandung: Alumni, 1976), h. 6

${ }^{10}$ Sidharta, Karakteristik Penalaran Hukum dalam Konteks Keindonesiaan (Bandung: Utomo Press, 2008), h. 422.
}

1945 yang mengatur kehidupan politik dapat disebut sebagai konstitusi politik (political constitution). Undang-Undang Dasar 1945 yang mengatur kehidupan ekonomi merupakan konstitusi ekonomi (economic constitution), Undang-Undang Dasar 1945 yang mengatur kehidupan sosial merupakan konstitusi sosial (social constitution).

Upaya mewujudkan kesejahteraan rakyat beranjak pada paradigma hukum dan nilainilai hukum di dalam konstitusi sebagaimana tertuang dalam pasal 33 dan 34 UndangUndang Dasar 1945, yang merupakan dimensi pengaturan ekonomi dan kesejahteraan sosial. Pengaturan dimaksud yang berciri demokrasi ekonomi-sosial sebagai berikut: 1) Perekonomian disusun sebagai usaha bersama berdasar atas azas kekeluargaan; 2) Cabang-cabang produksi yang penting bagi negara dan yang menguasai hajat hidup orang banyak dikuasai oleh negara; 3) Bumi, air dan kekayaan alam yang terkandung didalamnya dikuasai oleh negara dan dipergunakan untuk sebesar-besarnya kemakmuran rakyat; 4) Perekonomian Indonesia diselenggarakan berdasar atas demokrasi ekonomi dengan prinsip kebersamaan, efisiensi berkeadilan, berkelanjutan, berwawasan lingkungan, kemandirian, serta dengan menjaga keseimbangan kemajuan dan kesatuan ekonomi nasional; 5) Ketentuan lebih lanjut mengenai pelaksanaan pasal ini diatur dalam undang-undang.

Pengaturan nilai-nilai filosofis di dalam Pasal 33 Undang-Undang Dasar Negara Republik Indonesia Tahun 1945 berlandaskan pada semangat kekeluargaan, yang menempatkan penguasaan negara atas sumber daya alam untuk kepentingan publik. Pengaturan ini berdasarkan anggapan bahwa pemerintah adalah pemegang mandat untuk melaksanakan kehidupan berbangsa dan bernegara. Untuk itu, pemegang mandat ini seharusnya punya legitimasi yang sah dan ada yang mengawasi kebijakan yang dibuat maupuan dijalankannya, sehingga dapat tercipta peraturan perundangundangan sebagai penjabaran Pasal 33 UndangUndang Dasar 1945 yang sesuai dengan semangat demokrasi ekonomi sosial. Globalisasi di 
dalam perkembangannya telah mempengaruhi penerapan Pasal 33 Undang-Undang Dasar 1945. Peraturan perundang-undangan yang terkait dengan sektor-sektor ekonomi di Indonesia yang sejogyanya berdasarkan Pasal 33 Undang-Undang Dasar 1945. Akan tetapi dalam pelaksanaannya untuk membentuk peraturan perundang-undangan dihadapkan pada intervensi kekuatan politik dan ekonomi yang tidak berdasarkan pada nilai-nilai filosofis yang sesuai dengan Pasal 33 Undang-Undang Dasar 1945.

Sehubungan denganitu telah dilakukan beberapa kajian pada penelitian sebelumnya sebagaimana telah dilakukan enelitian oleh Jimly Asshidiqie bahwa Undang-Undang Dasar 1945 telah mengadopsi penyelenggaaraan perekonomian berdasar atas demokrasi ekonomi dengan prinsip kebersamaan, efisisensi berkeadilan, berkelanjutan, berwawasan lingkungan, kemandirian, serta dengan menjaga keseimbangan kemajuan dan kesatuan ekonomi nasional. Pada tataran praktis masih dibutuhkan pengaturan dan penerapan dalam praktek kehidupan bernegara. ${ }^{11}$ Pengkajian berikutnya berkaitan dengan upaya untuk menjaga perekonomian nasional agar tetap kokoh, sehat dan stabil maka dibutuhkan sinergitas penataaan struktur, subtansi kegiatan perekonomian dan penguatan budaya melalui perwujudan nilai-nilai dan penormaan perekonomian yang efisisen dan berkeadilan kedalam peraturan perundang-undangan. Pengaturan dan penerapan ketentuan yang diamanatkan konstitusi telah mengelaborasi prinsip kebersamaan, efisiensi berkeadilan dalam kegiatan ekonomi sebagaimana telah diatur dalam Undang-Undang Perbankan Syariah. ${ }^{12}$ Pengkajian terhadap politik hukum pembentukan peraturan perundang-undangan dibidang ekonomi syariah untuk mewujudkan kesejahteraan rakyat menurut Pasal 33 UUD 1945. Pengkajian hukum tersebut mengangkat permasalahanlandasankeberlakuan pembentukan

\footnotetext{
${ }^{11}$ Jimly Asshiddiqie, Konstitusi Ekonomi, h. 247

${ }^{12}$ Jundiani, Pengaturan Hukum Perbankan Syariah di Indonesia (Malang: UIN-Malang Press, 2007), h. 34
}

peraturan perundang-undangan di bidang ekonomi syariah dan pengaturan asas-asas dalam pembentukan peraturan perundangundangan dibidang ekonomi syariah menurut Pasal 33 UUD 1945. Tujuan pengkajian adalah untuk menentukan landasan berlakunya politik hukum pembentukan peraturan perundangundangan di bidang ekonomi syariah. Upaya peningkatan kegiatan ekonomi telah memberikan kontribusi peningkatan pendapatan ekonomi masyarakat. ${ }^{13}$

\section{Metode Penelitian}

Penelitian ini termasuk dalam penelitian hukum normatif. Dalam penelitian tersebut, telah dilakukan pengkajian terhadap antinomi nilai-nilai filosofis Pasal 33 Undang-Undang Dasar 1945 sebagai prinsip demokrasi sosial dan ekonomi. Pendekatan masalah yang dipakai dalam penelitian ini adalah dengan pendekatan konseptual (conceptual approach) dan pendekatan perundang-undangan (statute approach). Sumber bahan hukum penelitian terhadap nilai-nilai filosofis Pasal 33 Undang-Undang Dasar 1945 untuk sebesar-besar kemakmuran rakyat. Pengumpulan bahan hukum dilakukan dengan menggunakan metode studi kepustakaan yang dilakukan secara sistematis terhadap peraturan perundang-undangan yang dapat ditelusuri dalam himpunan peraturan perundangundangan yang ada. ${ }^{14}$ Penelusuran kepustakaan dilakukan untuk mendapatkan bahan hukum primer (yaitu peraturan perundang-undangan) serta bahan hukum sekunder, diantaranya adalah pandangan dari para ahli. ${ }^{15}$ Penelusuran teori-teori hukum, konsep, serta prinsip yang berkaitan dengan paradigma hukum dan nilainilai filosofis Pasal 33 Undang-Undang Dasar 1945 dalam penyelenggaraan demokrasi sosial

${ }^{13}$ Jundiani. Politik hukum Pembentukan Peraturan Perundang-Undangan di Bidang Ekonomi Syariah di Indonesia, Penelitian tidak diterbitkan, (Malang: Fakultas Syariah UIN Malang, 2014), h. 2

${ }^{14}$ P.M. Hadjon, Pengkajian Ilmu Hukum Dogmatik (normatif), Majalah Yuridika FH Unair, No. 6 (1997), h. 14.

${ }^{15}$ Gregory Churchill, Petunjuk Penelusuran Literatur Hukum Indonesia, (Jakarta: FH Universitas Indonesia, 1991), h. 4. 
dan ekonomi untuk mewujudkan sebesarbesar kemakmuran rakyat. Selanjutnya, dalam mencermati peraturan hukum diperlukan bantuan ajaran interpretasi. ${ }^{16}$

\section{Antinomi Nilai-Nilai Filosofis Pasal 33 Undang-Undang Dasar 1945.}

Di dalam penelusuran secara historis yuridis mengenai kehidupan ketatanegaraan Indonesia telah dapat diketahui bahwa bapak pendiri negara (The Founding Fathers) telah memikirkan bentuk dasar negara yang sesuai untuk negara Indonesia. Dari hasil kajian telah diupayakan perumusan pemikiran yang disampaikan oleh Bung Karno bahwa Pancasila sebagai Dasar Negara Indonesia. Pemikiran tersebut berkembang dari hasil perenungan atas berbagai pemikiran yang bersitegang (antinomi) nilai-nilai filosofis yang berkembang dalam peradaban kehidupan di muka bumi. Hasil pemikiran dimaksud telah disampaikan pada tanggal 1 Juni 1945 dalam rapat pleno Badan Penyelidik Usaha-Usaha Persiapan Kemerdekaan Indonesia. Hasil pemikiran tersebut yaitu Ketuhanan, Internasionalisme atau Perikemanusiaan, Kebangsaan, Mufakat atau Demokrasi, dan Kesejahteraan Sosial. Intisari pemikiran dimaksud adalah sosialisme baik terkait nasionalisme maupun demokrasi. Pemikiran yang demikian itu mengarah pada semangat kekeluargaan yaitu gotong royong.

Hasil pemikiran para pendiri negara berupa Pancasila sebagai dasar negara telah dimuat didalam Pembukaan Undang Undang Dasar 1945. Upaya para pendiri negara meletakkan didalam Pembukaan Undang Undang Dasar 1945 menjadikan Pancasila sebagai sumber cita kehidupan berbangsa dan bernegara Indonesia. Dalam dinamika proses-proses kemasyarakatan, Pancasila diwujudkan dalam berbagai bidang kehidupan berbangsa dan bernegara Indonesia. Pengaturan tatanan

\footnotetext{
${ }^{16} \mathrm{~W}$. Poespoprodjo, Interpretasi, (Bandung: Remadja Karya, 1987), h. 63.
}

hukum sebagai suatu sistem aturan hukum positif yang merupakan derivasi atau turunan dari dasar negara yaitu Pancasila.

Pancasila merupakan sumber hukum bagi berbagai bentuk hukum di Indonesia yang didasarkan pada paradigma hukum dan nilai-nilai hukum yang ada dalam kehidupan masyarakat Indonesia. Di dalam aturan hukum dimaksud menumbuhkan kewibawaan penguasa dan kepatuhan dari rakyat yang berdasarkan kesadaran dan rasa keadilan. Kepatuhan yang bersifat partisipatif sesuai nilai-nilai yang terkandung dalam pembukaan Undang Undang Dasar 1945 sebagai derivasi cita hukum Pancasila. Pembukaan Undang Undang Dasar 1945 sebagai norma dasar negara dan pasalpasal Undang Undang Dasar 1945 sebagai landasan hukum positif Indonesia.

Pembukaan dan Pasal-pasal Undang Undang Dasar 1945 merupakan sumber dari keseluruhan politik hukum nasional Indonesia. Pengaturan keduanya sebagai sumber politik hukum nasional didasarkan pada pemahaman yaitu Pembukaan dan Pasal-pasal Undang Undang Dasar 1945 memuat tujuan, dasar, cita hukum, dan norma dasar negara Indonesia yang harus menjadi tujuan dan pijakan dari politik hukum di Indonesia. Berikutnya, Pembukaan dan Pasalpasal Undang Undang Dasar mengandung nilai-nilai khas yang bersumber dari pandangan dan budaya bangsa Indonesia yang diwariskan oleh nenek moyang sejak berabad-abad yang lalu. Berdasarkan pemahaman tersebut berarti adanya kesamaan dalam memandang Pembukaan Undang Undang Dasar 1945 sebagai nilai-nilai yang sudah mengakar dalam kehidupan bangsa Indonesia dan harus menjadi landasan dalam menentukan arah kebijakan dan aturan hukum dalam penyelenggara negara dan pemerintahan. Penentuan arah dan kebijakan tersebut berdasarkan produk hukum yang berjiwa Pancasila. Pokok pikiran yang terkandung dalam ideologi hukum telah ditentukan secara yuridis filosofis dalam Pembukaan Undang Undang Dasar 1945 bahwa persatuan dengan mewujudkan keadilan sosial atau disingkat persatuan, 
keadilan bagi seluruh rakyat, kerakyatan dan permusyawaratan perwakilan, dan Ketuhanan Yang Maha Esa menurut dasar kemanusiaan yang adil dan beradab.

Dalam dinamika kehidupan kemasyarakatan menunjukan cita hukum berfungsi sebagai penentu arah bagi tercapainya cita-cita masyarakat. Cita masyarakat didalam kehidupan tidak sepenuhnya tergapai akan tetapi cita hukum telah memberi arah bagi keberlakuan hukum positif dalam mengatur kehidupan berbangsa dan bernegara. Cita hukum mendekatkan pada pemahaman konsep keadilan yang dapat memperkuat keberlakuan hukum. Tujuan Hukum yang tertib berkeadilan adalah hukum yang diarahkan oleh cita hukum yang sejalan dengan pencapaian tujuan-tujuan masyarakat. Cita hukum bukan hanya berfungsi sebagai tolok ukur yang bersifat regulatif dalam mengatur hubungan hukum yang berjalan harmonis, melainkan dapat berfungsi dalam penentuan hukum tertentu yang berarti ketiadaan cita hukum, menjadikan hukum tanpa makna.

Cita hukum berfungsi sebagai asas umum yang memberi petunjuk, norma kritik (kaidah evaluasi) dan faktor yang memotivasi dalam penyelenggaraan hukum (pembentukan, penerapan, penegakan dan penemuan) dan perilaku hukum. Hukum dalam hubungannya dengan Cita Hukum mengandung pula suatu pedoman dan suatu ukuran umum tentang apa yang harus dilihat sebagai hukum di dalam budaya yang bersangkutan. Cita hukum adalah merupakan sesuatu yang di dalamnya mengandung unsur-unsur yang emosional dan ideal, yang batasan rasionalnya tidak pasti. Pengertian dari konsepsi hukum yang berusaha mewujudkan cita hukum harus memenuhi tuntutan bahwa hal tersebut dapat dikerjakan. Untuk itu diperlukan unsur-unsur dari konsepsi hukum yang dapat dinilai dan merupakan sesuatu yang rasional dan aplikatif. Unsur-unsur yang rasionil dari cita hukum tersebut berakumulasi menjadi suatu konsepsi hukum sehingga dapat disusun suatu pengertian hukum umum menurut apa yang dikandung dan dimaksud oleh cita hukum yang bersangkutan. Unsur-unsur konsepsi hukum ini, adalah merupakan unsur-unsur yang di dalam mengandung bahan-bahan dasar idiil tentang aturan-aturan hukum selanjutnya yang diperlukan. Bahan-bahan idiil yang tersimpan di dalam unsur-unsur konsepsi hukum tersebut merupakan apa yang disebut dengan asas-asas hukum, yaitu pikiran dasar atau yang fundamentil dari hukum yang bersangkutan.

Cita hukum menjadi pangkal tolak hubungan antara masyarakat dengan hukum sebagai kesatuan yang tidak dapat dipisahkan. Cita hukum merupakan ide pokok dalam pemahaman ubi societas ibi ius. Pernyataan ini berarti dimana ada masyarakat maka di situ ada hukum. Fungsi dan tujuan hukum untuk mengatur kehidupan masyarakat dalam menjalankan aktivitas kehidupannya, sehingga melalui pengaturan hukum akan terwujud kesatuan masyarakat yang sejahtera, sesuai dengan yang diamanatkan dari tujuan bernegara indonesia yang tercantum dalam pembukaan Undang Undang Dasar 1945. Didalam kehidupan bermasyarakat, hukum berfungsi untuk menciptakan, memelihara dan mempertahankan kedamaian pergaulan hidup, selain juga berfungsi sebagai sarana untuk memperlancar proses interaksi para pihak yang saling berkepentingan.

\section{Nilai-Nilai Konstitusi dalam Undang Undang Dasar 1945}

Konstitusi adalah hukum tertinggi suatu negara. Berdasar konstitusi negara dapat disusun penyelenggaraan negara. Konstitusi mengatur penyelenggaraan dalam kehidupan berbangsa dan bernegara. Sebagai hukum dasar dapat diwujudkan dalam bentuk tertulis sehingga dapat disebut sebagai konstitusi tertulis. Pengaturan isi dari konstitusi suatu negara menjadi penting dan harus memiliki nilai-nilai normatif dan tujuan bernegara yang dituangkan dalam pengaturan pasal-pasal yang tercantum didalamnya. Di dalam praktik ketatanegaraan sering pula terjadi, bahwa suatu konstitusi yang tertulis tidak berlaku secara sempurna, karena salah satu atau beberapa pasal didalamnya tidak dijalankan lagi, sehingga konstitusi tidak lebih hanya untuk 
kepentingan penguasa saja, namun banyak pula konstitusi yang dijalankan sesuai dengan pasal-pasal yang ditentukannya.

Sehubungan dengan hal itu, Karl Loewenstein menjelaskan tiga macam nilai, yaitu; (1) normative value; (2) nominal value; (3) semantical value. Setiap konstitusi selalu terdapat dua aspek penting, yaitu sifat idealnya sebagai teori (das sollen) dan sifat nyatanya sebagai praktik (das sein). Suatu konstitusi yang mengikat itu bila dipahami, diakui, diterima, dan dipatuhi oleh masyarakat bukan hanya berlaku dalam arti hukum, akan tetapi juga merupakan suatu kenyataan yang hidup dalam arti sepenuhnya diperlukan dan efektif, maka konstitusi tersebut dinamakan konstitusi yang mempunyai nilai normatif. Akan tetapi, suatu konstitusi sebagian atau seluruh materi muatannya, dalam kenyataannya penerapannya tidak optimal. Penerapan yang demikian itu dalam penyelenggaraan kegiatan bernegara menunjukkan konstitusi tersebut bernilai nominal. Dalam praktiknya dapat pula terjadi percampuran antara nilai nominal dan normatif. Hanya sebagian saja dari ketentuan undang-undang dasar yang dilaksanakan, sedangkan sebagian lainnya tidak dilaksanakan dalam praktik, sehingga dapat dikatakan bahwa yang berlaku normatif hanya sebagaian, sedangkan sebagaian lainnya hanya bernilai nominal. Suatu konstitusi disebut konstitusi yang bernilai semantik jika norma-norma yang terkandung didalamnya secara hukum tetap berlaku, namun dalam kenyataannya adalah sekedar untuk memberikan bentuk dalam memperkuat kekuasaan politik penguasa.

Nilai konstitusi Indonesia sebelum dilakukan amandemen memiliki kecenderungan konstitusi yang bernilai semantik. Penyelenggaraan ketatanegaraan baik pada zaman Orde baru dan Orde lama pada waktu itu bertekad untuk melaksanakan secara murni dan konsekuen, akan tetapi dalam praktiknya keberlakuan itu semata-mata hanya untuk kepentingan kekuasaan politik penguasa. Paradigma hukum dan nilai-nilai hukum belum diwujudkan secara optimal dalam penyelenggaraan kehidupan politik, ekonomi dan sosial. Pasca perubahan Undang-Undang Dasar 1945 amandemen ke-4, memberikan nilai konstitusi bersifat normatif. Pengaturan nilai dan penormaan pada pasal 33 ayat (3), yang berbunyi "Bumi dan air dan kekayaan alam yang terkandung didalamnya dikuasai oleh negara dan dipergunakan untuk sebesar-besarnya kemakmuran rakyat". Kata dipergunakan dalam ayat dimaksud menunjukkan penerapannya masih belum optimal. Hal demikian dapat ditunjukkan terjadinya eskploitasi sumber daya alam oleh perusahaan asing yang sebagian besar keuntungannya kembali ke negara asalnya. Pengaturan yang demikian belum optimal dalam pencapaian tujuan yakni sebesarbesar kemakmuran rakyat. Demikian pula pengaturan mengenai kesejahteraan sosial sebagaimana termuat dalam pasal 34 ayat (1), yang berbunyi " Fakir miskin dan anakanak yang terlantar dipelihara oleh negara". Penerapan ketentuan dipelihara oleh negara terhadap fakir miskin dan anak-anak terlantar belum berjalan secara optimal sehingga belum mewujudkan kemakmuran seluruh rakyat Indonesia. Dengan demikian perubahan Undang Undang Dasar 1945 masih menunjukan nilai nominal karena ketentuan tersebut belum dijalankan secara optimal. Hal ini berarti di dalam kenyataan tidak semua pasal dalam konstitusi berlaku secara menyeluruh, hanya beberapa pengaturan dalam arti sepenuhnya diperlukan dan efektif dan dijalankan secara murni dan konsekuen.

Pasal33 Undang Undang Dasar 1945 memiliki nilai konstitusi nominal karena menjadi salah satu pasal yang hingga kini tak kunjung terealisasi semenjak Indonesia merdeka. Hal itu bisa dilihat dalam sidang uji materi beberapa undang-undang di Mahkamah Konstitusi. Para pemohon berkepentingan mewujudkan nilai konstitusi normative. Penilaian ditujukan pada ketiga undang-undang yang berlaku di sektor keuangan diamaksud adalah bertentangan dengan konstitusi dan berpotensi merugikan kepentingan negara dan masyarakat. Selain ketiga undang-undang di sektor ekonomi itu, masih banyak ketentuan undang-undang yang dianggap tidak sesuai dengan prinsip konstitusi. Perwujudan nilai konstitusi normative yaitu 
prinsip ekonomi kerakyatan adalah membangun kekuatan yang dimiliki oleh bangsa sendiri. Membangun nilai konstitusi normative untuk mewujudkan tujuan bernegara. Polemik hukum di persidangan Mahkamah Konstitusi terjadi berkaitan dengan peristilahan hukum 'Hak Menguasai Negara' atau HMN sebagaimana tercantum dalam dalam Pasal 33 Undang Undang Dasar 1945. Majelis Hakim Konstitusi dalam pertimbangan hukum membuat tafsir 'HMN' bukan dalam makna kepemilikan oleh negara. Akan tetapi, HMN dimaknai bahwa negara hanya merumuskan kebijakan (beleid), melakukan pengaturan (regelendaad), melakukan pengurusan (bestuurdaad), melakukan pengelolaan(beheersdaad), dan melakukan pengawasan (toezichtoundaad).

Semangat dari penyelenggara negara untuk mengangkat nilai konstitusi secara normative telah dilakukan Mahkamah Konstitusi dalam menafsirkan HMN yang tidak jauh berbeda dengan hasil sidang majelis Badan Penyelidik Usaha Persiapan Kemerdekaan Indonesia (BPUPKI). Mohammad Hatta membuat tafsir terkait pengertian hak menguasai negara yaitu pemerintah yang mewakili negara untuk menjadi pengawas maupun pengatur. Pemerintah bukan hanya menjadi pengawas dan pengatur bagi rakyat, akan tetapi 'tanah' hingga 'perusahaan tambang' dijalankan sebagai usaha Negara. Penerapan pasal 33 Undang Undang Dasar 1945 harus didasarkan pada pengawasan sehingga perekonomian menjadi mandiri. Hal ini perlu dilakukannya restrukturisasi posisi perekenomian Indonesia.

\section{Supremasi Hukum dan Antinomi Nilai-Nilai Filosofis}

Di dalam rangka mewujudkan nilai konstitusi normatif telah diakomodasikan dalam negara hukum. Negara hukum menempatkan kekuasaan tertinggi pada hukum dan bukan pada kekuasaan yang absolut. Indonesia dicita-citakan oleh the founding fathers sebagai suatu Negara Hukum. Pasal 1 ayat (3) Undang Undang Dasar 1945 menegaskan bahwa Negara Indonesia adalah Negara Hukum. Akan tetapi bagaimana menyusun cetak biru dan rancang bangun dari penjabaran ide negara hukum pada dasarnya adalah belum pernah dirumuskan secara komprehensif. Penuangan ide negara hukum hanya bersifat parsial yaitu pembangunan bidang hukum yang bersifat sektoral. Oleh karena itu, untuk mewujudkan nilai konstitusi normative maka supremasi hukum hendaknya dapat dipahami dan dikembangkan sebagai satu kesatuan sistem. Sehubungan dengan pemahaman supremasi hukum dengan kekuasaan, pada umumnya masyarakat menyamakan pengertian kekuasaan (power) dengan kekuatan (force). Hal ini berarti siapapun yang memiliki kekuatan (fisik) dapat menunjukkan kekuasaan. Kekuasaan tidak selalu bersumber pada kekuatan (fisik) karena di dalam kehidupan sehari-hari ditemukan orang yang berfisik lemah namun mempunyai kekuasaan. Kekuasaan sering bersumber pada wewenang formal (formal authority). Kewenangan formal yang bersumber pada hukum akan memberikan seseorang untuk berkuasa melakukan sesuatu yang bertujuan untuk menegakkanhukum. Hukum memerlukan kekuasaan. Tanpa kekuasaan, maka penegakan hukum sulit terlaksana. Sehingga dapat dikatakan hukum tanpa kekuasaan adalah anganangan, dan kekuasaan tanpa hukum adalah kelaliman. Hukum memerlukan kekuasaan bagi pelaksanaannya, sebaliknya kekuasaan itu ditentukan batas-batasnya oleh hukum. Selain wewenang resmi (formal authority), kekuasaan merupakan unsur mutlak dalam suatu masyarakat hukum. Kekuasaan pada dasarnya adalah kemampuan seseorang untuk memaksakan kehendaknya atas pihak lain.

Supremasi hukum sejalan denga konsep the rule of law yang diartikan sebagai pemerintahan oleh hukum, bukan oleh manusia (the governance not by man but by law). Hal ini berarti bukan hukumnya yang memerintah, karena hukum itu hanyalah kaedah atau pedoman dan sekaligus sarana atau alat, tetapi harus ada manusia sebagai subyek hukum yang berkepentingan untuk melaksanakannya secara konsisten berdasarkan hukum, dan tidak sekehendak atau sewenang-wenang dari pelaksananya. Hukum itu diciptakan atau direkayasa oleh manusia, 
terutama hukum tertulis. Setelah hukum itu tercipta maka manusia terikat pada hukum, harus tunduk pada hukum. Hal ini tidak lain adalah untuk kepentingan manusia itu sendiri. Hukum harus mempunyai kekuasaan tertinggi demi kepentingan manusia itu sendiri, tetapi sebaliknya manusia tidak boleh diperbudak oleh hukum. Governance not by man but by law, berarti bahwa tindakan-tindakan resmi (pemerintah) pada tingkat teratas sekalipun harus tunduk pada peraturan-peraturan hukum.

Di dalam rangka perwujudan nilai konstitusi yang bersifat normative maka penegakan hukum harus didasarkan pada supremasi hukum untuk mencapai tujuannya yaitu kepastian hukum, keadilan, ketertiban, ketentraman, kedamaian dan kesejahteraan. Pemikiran nilainilai filosofis mengungkapkan bahwa hukum berdiri pada tiga nilai dasar pertimbangan yaitu nilai keadilan, nilai kepastian hukum dan nilai kemanfaatan hukum. Pertimbangan pada nilai keadilan diwujudkan dengan peraturan yang dianggap adil dan berlaku pada kehidupan di masyarakat sesuai cita hukum. Hukum dilihat sebagai suatu nilai kepastian, mengandung arti bahwa kaidah dan norma yang mewajibkan dan telah ditetapkan dalam suatu peraturan perundang-undangan yang sah harus dipandang sebagai sarana untuk mewujudkan aturan yang adil tersebut. Sedangkan hukum dilihat sebagai suatu sarana yang menghasilkan kemanfaatan atau kegunaan mendasarkan pada pemahaman bahwa keberadaan hukum tersebut membawa kemanfaatan bagi kehidupan di masyarakat.

Perbedaan diantara ketiganya sebagai nilai filosofis terungkap di dalam penerapannya yaitu keberadaan hukum haruslah mengandung ketertiban yang dapat memenuhi tuntutan keadilan. Peraturan perundang-undangan yang menunjukkan nilai-nilai dan penormaan yang bersifat menjaga ketertiban in casu kepastian hukum yang diharapkan pada kenyataannya dapat memenuhi tuntutan keadilan di dalam penyelenggaraan pemenuhan kebutuhan hukum masyarakat. Beranjak dari upaya penyelenggaraan kehidupan yang berdasarkan hukum maka tak dapat dihindari suatu pemahaman tentang hukum yang sejogyanya hukum yang dapat memberikan kemanfaatan secara optimal dalam kehidupan bermasyarakat. Relasi nilai filosofis diantara nilai kepastian hukum, nilai keadilan hukum dalam berbagai sumber hukum formal merupakan hal yang dikehendaki oleh masyarakat dalam rangka pemenuhan tujuan hukum dimaksud.

Antinomi nilai-nilai filosofis hukum secara alamiah terjadi pada penyelenggara hukum di masyarakat. Di dalam rangka mewujudkan konsistensi nilai konstitusiyang bersifat normative maka dibutuhkan penyelenggaraan hukum yang menjaga kepentingan secara proposional di antara nilai-nilai yang hendak dibangun dalam peristiwa hukum di masyarakat. Hal demikian ini menjadi tantangan bagi penyelenggaraan hukum agar dapat mengakomodasikan ketiga nilai hukum di maksud. Sumber hukum formal menjadi pangkal tolak pemenuhan kebutuhan masyarakat atas hukum yang memenuhi secara proposional nilai nilai hukum dimaksud tanpa menimbulkan kevakuman hukum atau ketidaktertiban dalam masyarakat. Dominansi nilai kepastian hukum sering tak bisa dihindari para penyelenggaraan negara dalam pemenuhan hukum para warganya. Hal ini tidak menjadi pesoalan manakala kualitas hukum telah memenuhi kebutuhan hukum masyarakat dari sisi keadilan hukum maupun kemanfaatan hukumnya. Akan tetapi telah menjadi kebiasaan dalam praktek penyelenggaraan manakala produk hukum tidak berkualitas diantaranya, terjadinya tumpang tindih, tidak konsisten maupun tafsir yang bias/ganda maka pemenuhan nilai-nilai hukum tidak berjalan secara optimal.

Fungsi hukum dapat dijalankan atas dasar kekuasaan yang bersifat beraneka ragam bentuknya (polyform) maupun sumbernya, diantaranya bersumber pada kekuatan fisik, kekuasaan ekonomi atau tingkat pemahaman dan pengamalan agama yang tinggi dalam diri seseorang. Fungsi hukum dijalankan oleh pihak yang berkepentingan berdasarkan kejujuran sebagai moral positif sekaligus sumber suatu bentuk kekuasaan yang disebut wibawa sehingga dapat memaksakan kehendaknya pada orang- 
orang yang dalam penguasaannya. Pemegang kekuasaan tidak boleh orang yang bermoral rendah sehingga harus ada persiapan moral untuk dapat menjadi penguasa. Penguasa yang baik adalah yang memiliki semangat mengabdi kepada kepentingan umum (sense of public service). Demikian pula sikap dari orang yang dikuasai adalah kewajiban tunduk pada penguasa (the duty of civil obedience).

Sinergitas fungsi hukum dalam pemenuhan kebutuhan masyarakat dengan kekuasaan yang berbentuk kewenangan formal. Kekuasaan di dalam negara hukum haruslah dibatasi oleh hukum. Kekuasaan didasarkan pada batasbatas kewenangan yang diberikan oleh hukum. Ketidakjelasan rumusan atau batasan mengenai kewenangan akan mengakibatkan adanya kecenderungan penyalahgunaan kewenangan. Batasan kewenangan dari pemegang kekuasaan harus dituangkan dalam suatu peraturan perundang-undangan. Rakyat melalui wakilwakilnya dapat melakukan pengawasan terhadap kinerja dari pemegang kekuasaan. Apabila ada pejabat yang melalukan penyalahgunaan kewenangan, maka pasti disitu telah terjadi suatu pelanggaran norma sehingga masyarakat yang pasti akan dirugikan. Dengan demikian keberadaan hukum yang didasarkan pada kekuasaan yang berupa kewenangan formal dalam masyarakat sangat esensial karena fungsi hukum itu sendiri selain untuk menegakkan keadilan, menjaga ketertiban, dan keamanan, hukum juga dapat digunakan sebagai pengatur sehingga kebutuhan masyarakat itu dapat terpenuhi.

\section{Aktualisasi Nilai-nilai Filosofi Pasal 33 UUD 1945}

\section{Konstitusi Ekonomi: Politik Hukum dalam Penyelenggaraan Ekonomi Nasional}

Pengkajian terkait dengan aktualisasi nilainilai filosofis Pasal 33 Undang Undang Dasar 1945 tidak dapat dilepaskan dengan politik hukumnya. Politik hukum sebagai penentu arah kebijakan hukum baik pengaturan hukum positif ius constitutum maupun hukum yang akan diberlakukan ius constituendum. Dengan dicantumkan ketentuan sebagaimana diatur dalam Pasal 33 Undang Undang Dsar 1945 yang merupakan penentu arah kebijakan ekonomi sehingga dapat dikualifikasikan sebagai Konstitusi Ekonomi. ${ }^{17}$ Pengaturan urusan politik ekonomi sebagaimana telah dirumuskan dalam Pasal 33 Undang Undang Dasar 1945sebagai berikut: 1) Perekonomian disusun sebagai usaha bersama berdasar kekeluargaan; 2) Cabang-cabang produksi yang penting bagi negara dan yang menguasai hajat hidup orang banyak dikuasai oleh negara; 2) Bumi dan air dan kekayaan alam yang terkandung didalamnya dikuasai oleh negara dan dipergunakan untuk sebesarbesar kemakmuran Rakyat. ${ }^{18}$

Pengaturan urusan politik hukum ekonomi telah diatur pula dalam Risalah Rapat Paripurna ke-5 Sidang Tahunan MPR Tahun 2002 Sebagai Naskah Perbantuan Dan Kompilasi Tanpa Ada Opini sebagai berikut : 1) Perekonomian disusun sebagai usaha bersama berdasar atas asas kekeluargaan; 2) Cabang-cabang produksi yang penting bagi Negara dan yang menguasai hajat hidup orang banyak dikuasai oleh Negara; 3) Bumi dan air dan kekayaan alam yang terkandung di dalamnya dikuasai oleh Negara dan dipergunakan untuk sebesar-besar kemakmuran rakyat; 4) Perekonomian nasional diselenggarakan berdasar atas demokrasi ekonomi dengan prinsip kebersamaan, efisiensi berkeadilan, berkelanjutan, berwawasan lingkungan, kemandirian, serta dengan menjaga keseimbangan kemajuan dan kesatuan ekonomi nasional; 5) Ketentuan lebih lanjut mengenai pelaksanaan pasal ini diatur dalam undang-undang.

Secara eksplisit rancang bangun politik hukum ekonomi telah dirumuskan dalam Pasal 33 UUD 1945. Melalui ayat 1 Pasal 33 UUD 1945 telah dimanatkan bahwa "Perekonomian disusun sebagai usaha bersama berdasarkan atas asas kekeluargaan". Pengaturan ayat tersebut dengan memuat peristilahan hukum yang membutuhkan penjelasan, yaitu "usaha

\footnotetext{
${ }^{17}$ Jimly Asshidiqie, Konstitusi Ekonomi, h. 1.

${ }^{18}$ Berita Repoeblik Indonesia Tahoen II No. 7, 15 Febroeari 1946 dan Lembaran Negara Republik Indonesia
} No.75, Tahun 1959. 
bersama" dan "asas kekeluargaan." Beranjak dari kedua peristilahan hukum dimaksud telah memberikan pemahaman dasar mengenai politik hukum ekonomi nasional yaitu perekonomian nasional menurut pemikiran The Founding Fathers adalah didasarkan pada semangat semangat kebersamaan yang merupakan kekayaan budaya masyarakat Indonesia in casu gotong royong. Semangat kebersamaan dapat diwujudkan dalam kehidupan ekonomi dengan membentuk "usaha bersama" dan bentuk badan usaha yang mencerminkan semangat gotong royong adalah koperasi. Penerapan "semangat gotong royong" ini berelasi dengan pemikiran The Founding Fathers untuk memarginalisasikan pemikiran individualistic/kapitalistik/liberalistic yang diwujudkan dalam persaingan bebas (free fight competition).

\section{Nilai-Nilai Filosofis Dalam Pasal 33 UUD 1945}

Sebagai wujud perjanjian sosial tertinggi, konstitusi memuat nilai-nilai filosofik yang telah diaktualisasikan para penyelenggara negara. Aktualisasi nilai-nilai filosofik merupakan pendorong cita-cita hukum yang akan dituju melalui pembentukan negara berdasarkan prinsip-prinsip dasar pencapaian cita-cita hukum dimaksud. Undang Undang Dasar Negara Republik Indonesia Tahun 1945 sebagai konstitusi bangsa Indonesia merupakan dokumen hukum dan dokumen politik yang memuat cita-cita, dasar-dasar, dan prinsip-prinsip penyelenggaraan kehidupan bernegara. Pasal II Aturan Tambahan Undang Undang Dasar 1945 menyatakan bahwa Undang Undang dasar Negara Republik Indonesia Tahun 1945 terdiri atas Pembukaan dan pasal-pasal. ${ }^{19}$ Menurut Jimly Asshidiqie, bahwa Pembukaan dan pasalpasal Undang Undang Dasar 1945 adalah satu kesatuan norma-norma konstitusi. Walaupun pembukaan memiliki tingkat abstraksi yang lebih tinggi dibanding pasal-pasal, namun tidak dapat dikatakan bahwa pembukaan memiliki kedudukan lebih tinggi dari pasal-pasal. 1945.

${ }^{19}$ Tahap Keempat Perubahan Undang Undang Dasar
Keduanya adalah norma-norma supreme dalam tata hukum nasional (national legal order). ${ }^{20}$ Untuk mencapai cita-cita sebagaimana dirumuskan dalam Pembukaan Undang Undang Dasar 1945 tersebut dan melaksanakan penyelenggaraan negara berdasarkan Pancasila, Undang Undang Dasar 1945 telah memberikan kerangka susunan kehidupan bermasyarakat, berbangsa, dan bernegara. Norma-norma dalam Undang Undang Dasar 1945 tidak hanya mengatur kehidupan politik tetapi juga kehidupan sosial dan ekonomi. Hal ini karena para pendiri negara menghendaki bahwa rakyat Indonesia berdaulat secara penuh, bukan hanya kedaulatan dalam politik. Oleh karena itu Undang Undang 1945 merupakan konstitusi politik, konstitusi ekonomi, dan konstitusi sosial yang menjadi acuan dan landasan secara politik, ekonomi, dan sosial, baik oleh negara (state), masyarakat (civil society), maupun pasar (market). ${ }^{21}$

Penafsiran hukum Pasal 33 Undang Undang 1945 dalam beberapa Putusan Mahkamah Konstitusi sudah sangat jelas, seperti putusan Pengujian Undang-Undang Ketenagalistrikan yang dibatalkan seluruhnya dan Putusan Pengujian Undang-Undang tentang Minyak dan Gas yang membatalkan 5 ayat, karena bertentangan dengan ketentuan dalam pasal 33 Undang Undang Dasar 1945. Yang dimaksud dengan penguasaan negara dalam Pasal 33 ayat (3) Undang Undang Dasar 1945, bukan sematamata pemilikan oleh negara. Pemilikan adalah konsep perdata, sedangkan penguasaan adalah konsep tata negara. Di dalam konsep menguasai tersebut tercakup pengawasan, pemilikan, pengelolaan dan sebagainya. Pengaturan penguasaan demikian itu merupakan kebijakan negara. Penentuan bagaimana kebijakan teknis penguasaan bergantung kepada komoditinya. Apakah suatu komoditi penting bagi negara atau menguasai hidup orang banyak atau tidak tergantung kondisi, situasi dan perkembangan

\footnotetext{
${ }^{20}$ Jimly Ashiddiqie, Politik Perekonomian Nasional (Online) (dapat diakses di http://www.jimly.com/ pemikiran/view/17, tanggal 22 Agustus 2015)

${ }^{21}$ Jimly Ashiddiqie. Politik Perekonomian
} 
zaman. ${ }^{22}$ Sehubungan dengan aktualisasi antinomi nilai-nilai filosofik terhadap Pasal 33 Undang Undang Dasar 1945 maka Menurut Jimly Asshidiqie bahwa seorang negarawan harus pandai-pandai melihat dan menilai dari banyak aspek. Jangan hanya melihat dari satu kacamata teori ekonomi saja. Pasal 33 Undang Undang Dasar 1945 janganlah dipahami secara kaku. Pasal 33 Undang Undang Dasar 1945 tidak anti privatisasi dan tidak juga anti swastanisasi. State hanya salah satu domain saja dari 3 (tiga) domain yang ada, yaitu state, civil society, dan market. Hakim harus adil di tengah-tengahnya, tidak bisa hanya memihak negara dalam pengertian sempit, begitu juga civil society, tidak juga berpihak kepada market. Ketiganya harus sama-sama kuat saling mengimbangi. Dalam sistem demokrasi moderen ketiganya saling menunjang dan harmoni. Dengan begitu demokrasi tumbuh sehat, dan di tengah demokrasi yang sehat kesejahteraan sosial pun tumbuh. ${ }^{23}$

\section{Aktualisasi Nilai-Nilai Filosofis dalam Penyelenggaraan Kegiatan Ekonomi}

Restrukturisasi posisi perekonomian Indonesia dilakukan untuk memenuhi kesejahteraan rakyat Indonesia. Pengawasan terhadap penyelenggaraan negara dibidang perekonomian sejogyanya dikontrol agar tetap berjalan sesuai dengan amanat Konstitusi. Pemerintah telah dianggap tidak sungguh-sungguh memperhatikan kesejahteraan rakyat, seperti yang kerap disampaikan dalam berbagai kesempatan. Pemerintah juga dianggap tidak serius menjalankan mandat konstitusi bahkan cenderung mengabaikannya. Salah satu mandat yang terabaikan itu adalah Pasal 33 UUD 1945: "Bumi, air dan kekayaan alam yang terkandung di dalamnya dikuasai oleh negara dan dipergunakan untuk sebesar-besar kemakmuran rakyat". Pasal ini merupakan salah satu prinsip mendasar bagaimana seharusnya sumberdaya perekonomian dikelola oleh negara. Aktualisasi nilai-nilai filosofik dalam Pasal 33 Undang

\footnotetext{
${ }^{22}$ Jimly Ashiddiqie. Politik Perekonomian

${ }^{23}$ Jimly Ashiddiqie, Politik Perekonomian
}

Undang Dasar 1945 telah diwujudkan dalam Pengaturan Production Sharing Contract yang berlaku di sektor minyak dan gas adalah satu-satunya model pengelolaan sumberdaya alam yang sesuai dengan amanat Pasal 33 Undang Undang Dasar 1945 sebagaimana ketentuan Production Sharing Contract sebelum berlakunya Undang Undang No 22 tahun 2001 tentang Migas. Production Sharing Contract mengatur prinsip dasar bahwa kepemilikan sumberdaya minyak dan gas ada di tangan negara (mineral right) in casu hak menambang (mining right), melalui perusahaan milik negara yang diberikan amanat oleh undang-undang. Adapun dalam pelaksanaannya, dapat melalui swasta asing atau dalam negeri dengan mempertimbangkan kemampuan teknis dan finansial negara. Namun, kedua prinsip dasar di atas tetap berlaku. Pihak swasta hanya berhak mengambil manfaat ekonomi (economic right) dari kegiatan penambangan minyak dan gas dimaksud setelah dilakukan penyerahan hak masing-masing baik yang diterima oleh swasta maupun negara

Melalui pengaturan tersebut maka selama minyak dan gas masih ada di bumi Indonesia, dan selama negara belum secara resmi memberikan hak yang menjadi bagian minyak dan gas yang ditambang itu kepada pihak swasta, selama itu pula penguasaan sumberdaya minyak dan gas tetap di tangan negara. Hal ini berbeda dengan penambangan umum seperti emas, batubara, dan sebagainya. Secara prinsip, sumberdaya tambang umum adalah sama kedudukannya dengan sumberdaya minyak gas sesuai dengan amanat konstitusi. Akan tetapi tambang migas yang menggunakan sistem Production Sharing Contract, sedangkan penambangan umum masih menggunakan sistem konsesi yaitu sistem yang berjalan sejak jaman colonial. Di dalam sistem konsesi, Pihak swasta nasional maupun asing, menguasai hak atas mineral (mineral right), hak menambang (mining right) dan hak atas manfaat ekonomi (economic right). Sistem konsesi tidak sejalan dengan apa yang disampaikan oleh Hatta mengenai sistem ekonomi yang sesuai dengan negara Indonesia. Beranjak dari nilai-nilai 
dan norma dalam Pasal 33 UUD 1945 yang pada pokoknya menganut asas kekeluargaan. Dalam Pasal itu dikatakan, cabang-cabang produksi yang penting bagi negara dan yang menguasai hajat hidup orang banyak dikuasai oleh Negara. Bumi dan air dan kekayaan alam yang terkandung di dalamnya dikuasai oleh negara dan dipergunakan untuk sebesar-besar kemakmuran rakyat.

\section{Kesimpulan}

Perumusan pemikiran tentang Pancasila sebagai dasar negara Indonesia beranjak dari pemikiran yang berkembang dari hasil perenungan atas berbagai pemikiran yang bersitegang (antinomi) nilai-nilai filosofis yang berkembang di dalam peradaban kehidupan di muka bumi. Sebagai negara yang berdasarkan Pancasila berkehendak dalam mewujudkan nilai konstitusi normatif maka supremasi hukum

\section{DAFTAR PUSTAKA}

Asshiddiqie, Jimly. Konstitusi Ekonomi. Jakarta: Penerbit Buku Kompas. 2010

Politik Perekonomian Nasional (Online) (dapat diakses di http://www. jimly.com/pemikiran/view/17, tanggal 22 Agustus 2015)

Churchill, Gregory. Petunjuk Penelusuran Literatur Hukum Indonesia. Jakarta: FH Universitas Indonesia. 1991

Hadjon, Philipus M. Pengkajian Ilmu Hukum Dogmatik (normatif). Majalah Yuridika FH Unair, No. 6. 1997

Jundiani. Pengaturan Hukum Perbankan Syariah di Indonesia. Malang: UIN-Malang Press. 2007

Politikhukum Pembentukan Peraturan Perundang-Undangan di Bidang Ekonomi Syariah di Indonesia, Penelitian tidak diterbitkan. Malang: Fakultas Syariah UIN Malang. 2014 hendaknya dapat dipahami dan dikebangkan dalam bentuk tertulis yang mengatur substansi penyelenggaraan suatu negara menjadi penting dan harus memiliki nilai-nilai normatif sesuai dengan tujuan bernegara yang dituangkan dalam pengaturan pasal-pasal yang tercantum di dalamnya. Pengkajian terkait dengan aktualisasi nilai-nilai filosofis pasal 33 UndangUndang Dasar 1945 tidak dapat dilepaskan dengan politik hukumnya. Politik hukum sebagai penentu arah kebijakan hukum baik pengaturan hukum positid ius constitutum maupun hukum yang akan diberlakukan ius constituendum. Konsitusi memuat nilai-nilai filosofis yang telah diaktualisasikan para penyelenggara negara. Aktualisasi nilai-nilai filosofis merupakan pendorong cita-cita hukum melalui pembentukan negara berdasarkan prinsi-prinsip dasar pencapaian cita-cita hukum dimaksud.

Kusuma, R.M. Ananda B. “Teori Konstitusi dan UUD 1945", Jurnal Konstitusi Mahkamah Konstitusi 3, No 2, Mei 2006

Kusumaatmadja, Mochtar. Konsep Hukum dalam Pembangunan. Bandung: Alumni. 1976

Poespoprodjo, W. Interpretasi. Bandung: Remadja Karya. 1987

Sidharta, Bernard Arief. Refleksi Tentang Struktur Ilmu Hukum: Sebuah Penelitian tentang Fundasi Kefilsafatan dan Sifat keilmuan Ilmu Hukum Sebagai Landasan Pengembangan Ilmu Hukum Nasional Indonesia. Bandung: Mandar Maju. 2003

Sidharta, Karakteristik Penalaran Hukum dalam Konteks Keindonesiaan. Bandung: Utomo Press. 2008

Thaib, Dahlan et.al.Teori dan Hukum Konstitusi. Jakarta: Rajawali Press, 1999 